[Agr. Biol. Chem., Vol. 34, No. 8, p. 1268 1271, 1970]

\title{
Formation of the Fructose-rich Polymer by Water-insoluble Dextransucrase and Presence of a Glycogen Value-lowering Factor
}

Sir:

Water-insoluble preparations of partially purified dextransucrase adsorbed on DEAESephadex A-50 were found to still catalyze polymerization reaction of sucrose and to synthesize the significant amounts of fructoserich polymer which had ability to interact with concanavalin A.

Furthermore, a factor in a crude enzyme preparation, possibly protein in nature, was found to control the glycogen values of the fructose-rich polymer produced by insoluble enzyme.

Dextransucrase excreted by Leuconostoc mesenteroides NRRL B-512 F was prepared by the procedure of Jeanes ${ }^{1 \prime}$ and partially purified according to the method of Suzuki ${ }^{2)}$ (20 fold in specific activity).

Water-insoluble enzyme was prepared by adsorbing the partially purified enzyme on DEAE-Sephadex A-50 column previously equilibrated with $0.3 \mathrm{M}$ acetate buffer, $\mathrm{pH} 5.2$. The gel-bound enzyme was used as the waterinsoluble enzyme.

From the reaction mixture of $20 \mathrm{~g}$ of waterinsoluble enzyme in $25 \mathrm{ml}$ of $0.3 \mathrm{M}$ acetate buffer, $\mathrm{pH} 5.2$ and $5 \mathrm{ml}$ of 609 sucrose solution in the same buffer, $1 \mathrm{~g}$ of white fluffy powder was obtained.

The properties of this polymer and dextran

1) A. Jeanes, "Methods in Carbohydrate Chemistry," Vol. V, ed. by R. L. Whistler, Academic Press Inc., New York, N.Y., 1965, p. 127.

2) Y. Suzuki and H. Katagiri, J. Vitaminology, 9, 285 (1963).
Table I. Glycogen Values and Fructose Contents of THE POLYMers Formed by EITHER MODIFIED WATER-INSOLUBLE ENZYME OR NATIVE ENZYME

\begin{tabular}{|c|c|c|}
\hline & $\begin{array}{l}\text { Glycogen } \\
\text { values }\end{array}$ & $\begin{array}{c}\text { Fructose } \\
(\%)\end{array}$ \\
\hline Polymer formed by insoluble enzyme & 0.58 & 15.0 \\
\hline $\begin{array}{l}\text { Polymer formed by water-soluble } \\
\text { native enzyme }\end{array}$ & 0.04 & 1.0 \\
\hline $\begin{array}{l}\text { Polymer partially hydrolyzed by } \\
0.1 \mathrm{~N} \mathrm{HCl*}\end{array}$ & 0.00 & 0.0 \\
\hline
\end{tabular}

* Polymer produced by insoluble enzyme was partially hydrolyzed by $0.1 \mathrm{~N} \mathrm{HCl}$ for $5 \mathrm{~min}$ in boiling water.

formed by native soluble enzyme are shown in Table I. Results indicate that the polymer formed by insoluble enzyme has higher glycogen value and fructose contents than dextran. If the polymer is a mixture of dextran and fructan the highly reactive property with concanavalin A seems mainly to be due to fructan, for after short time acid hydrolysis (in $0.1 \mathrm{~N} \mathrm{HCl}$, at $100^{\circ} \mathrm{C}$ for $5 \mathrm{~min}$ ) glycogen value of the partial hydrolyzate dramatically decreased as shown in Table I. NMR spectrum of this partial hydrolyzate also shows that it is a typical linear dextran, that is, it has a peak at $5.00 \mathrm{ppm}(\alpha-1,6$-linkage $)$ but no peak at $5.40 \mathrm{ppm}$ (non $\alpha$-1,6-linkage). ${ }^{31}$ In order to isolate the fructan from the mixture, interaction with concanavalin A was carried out as follows: The fructose-rich polymer was

3) W. M. Pasik and L. H. Cragg, Can. J. Chem., 41, 293 (1963). 


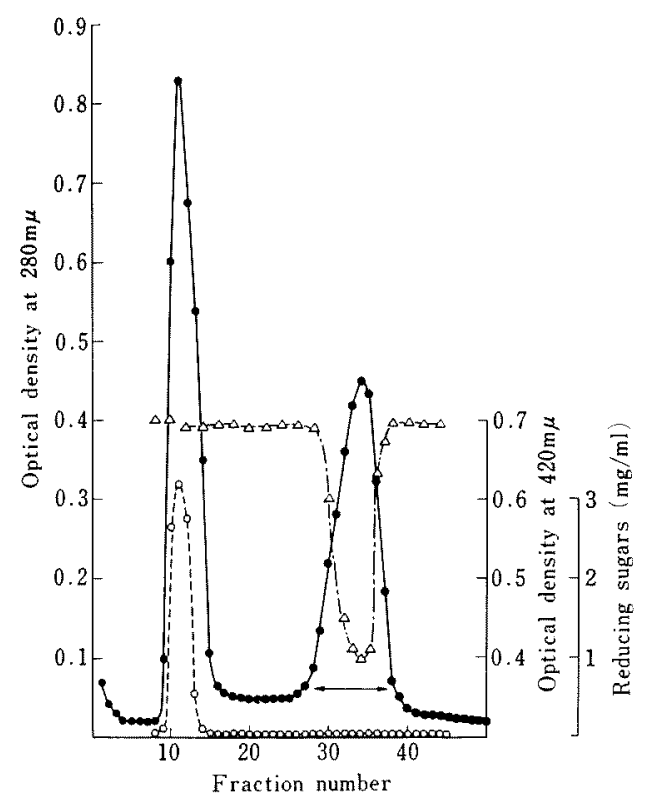

FIG. 1, Gel Filtration of the Factor which Inhibits the Synthesis of Fructose-rich Polymer on Sephadex G-100.

Fractions, each $5.0 \mathrm{ml}$ were collected. Protein distribution in eluate fractions (O.D.280 $\mathrm{m} \mu$ ), $0--O$ The activity which liberates the reducing sugars, $\Delta-\cdot-\Delta$ Glycogen value-lowering activity of the factor (O.D. $420 \mathrm{~m} \mu)$.

dissolved in water, and concanavalin A solution $\left(8.0 \mathrm{mg} / \mathrm{ml}\right.$, prepared as Agrawal et al. $\left.{ }^{41}\right)$ was added and stood for $20 \mathrm{~min}$.

The precipitate was collected by centrifugation, suspended in $1.0 \mathrm{M} \mathrm{NaCl}$ solution and D-mannose was added to dissociate the polymer from concanavalin A. After removal of the protein by heat coagulation and centrifugation, the opalescent supernatant solution was exhaustively dialyzed against distilled water, and a polymer was obtained by alcohol precipitation. The infrared spectrum of the polymer shows that it is a furanose derivative (absorption peaks; 810, 874 (weak), 925 (strong) and $985 \mathrm{~cm}^{-1}$ ). Hydrolysis of the

4) B. B. L. Agrawal and I.J. Goldstein, Biochem. $J ., 96,23 c(1965)$. polymer (in $0.1 \mathrm{~N} \mathrm{HCl}, 100^{\circ} \mathrm{C}$ for $1.5 \mathrm{hr}$ ) and analysis by paper chromatography indicate that the polymer which interacts with concanavalin $\mathrm{A}$ is consisted almost entirely of fructose.

Isolation of a factor which lowered glycogen value of the fructose-rich polymer produced by insoluble enzyme was carried out by gel filtration as follows: The portion which was not adsorbed on DEAE-Sephadex A-50 was concentrated by lyophilization and applied to Sephadex G-100 column previously equilibrated with $0.3 \mathrm{M}$ acetate buffer, $\mathrm{pH} 5.2$. A typical elution pattern from this column is shown in Fig. 1. The activity which lowers glycogen values was assayed by measuring the optical density at $420 \mathrm{~m} \mu$ of the supernatant solution of reaction mixture $(0.5 \mathrm{~g}$ of insoluble enzyme, $0.2 \mathrm{ml}$ of $60 \%$ sucrose and $1.0 \mathrm{ml}$ of eluate; incubated at $25^{\circ} \mathrm{C}$ for $15 \mathrm{hr}$ ). The linear relationship between glycogen values and optical densities at $420 \mathrm{~m} \mu$ of the

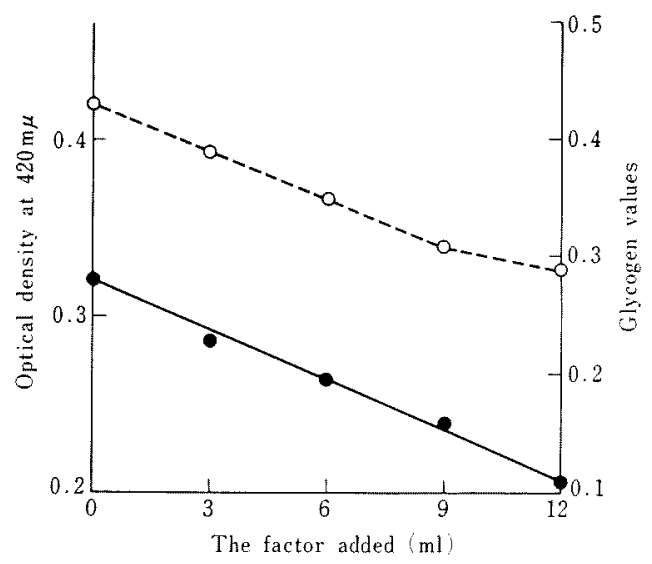

FIG. 2. The Effects of the Factor on the Synthesis of the Polymer by the Insoluble Enzymatic Derivatives.

The composition of the reaction mixtures were as follows: Insoluble enzymatic derivatives $1.0 \mathrm{~g}$, the factor $0,3.0,6.0,9.0$ and $12.0 \mathrm{ml}, 60^{\circ}$ sucrose $6.0 \mathrm{~mL}$ and total volume was adjusted to $18.0 \mathrm{ml}$ by $0.3 \mathrm{M}$ acetate buffer. $\mathrm{O} . \mathrm{D} .420 \mathrm{~m} \mu$ of the supernatant solution of reaction mixtures. $\mathrm{O}-\mathrm{m}$ Glycogen values. 
Table II. Glycogen Values and Fructose Contents of the Polymers Formed By Water-INSOLUble ENZYMe IN THE PRESEnCE oR ABSENCE of THE FaCtor

\begin{tabular}{cccccc}
\hline $\begin{array}{c}\text { Insoluble } \\
\text { enzyme }\end{array}$ & Factor & $\begin{array}{c}0.3 \mathrm{M} \mathrm{Acetate} \text { buffer } \\
(\mathrm{pH} \mathrm{5.2)}\end{array}$ & $60 \%$ Sucrose & $\begin{array}{c}\text { Glycogen } \\
\text { values }\end{array}$ & $\begin{array}{c}\text { Fructose contents } \\
(\%)\end{array}$ \\
\hline $0.5 \mathrm{~g}$ & - & $5.0 \mathrm{ml}$ & $1.0 \mathrm{ml}$ & 0.58 & 15.0 \\
$0.5 \mathrm{~g}$ & $5.0 \mathrm{ml}$ & - & $1.0 \mathrm{ml}$ & 0.14 & 14.0 \\
$0.5 \mathrm{~g}$ & $5.0 \mathrm{ml}$ & - & $1.0 \mathrm{ml}$ & 0.60 & 14.5 \\
\hline
\end{tabular}

* Heated for $5 \mathrm{~min}$ in boiling water before addition.

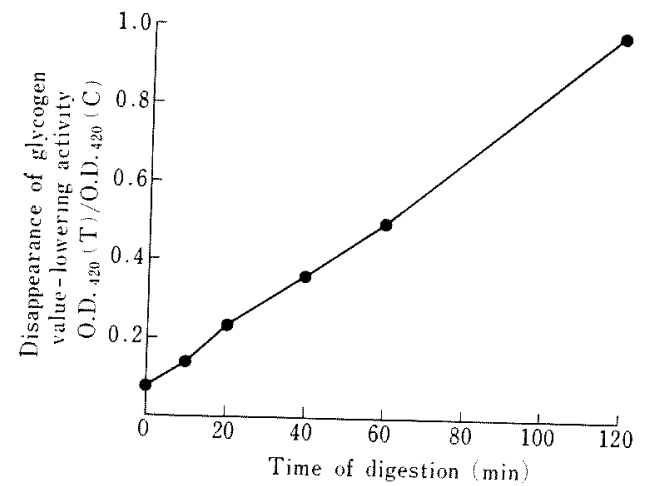

FIG. 3. Papain Digestion of the Factor.

The composition of reaction mixture for papain digestion was as follows: The factor $1.25 \mathrm{ml}$, $0.05 \mathrm{M}$ citrate buffer $(\mathrm{pH} 5.5) 0.5 \mathrm{ml}$, papain solution $0.25 \mathrm{ml}$, distilled water $0.5 \mathrm{ml}$; as a control $0.3 \mathrm{M}$ acetate buffer was replaced with the factor. After incubation at $37^{\circ} \mathrm{C}$ for the time indicated above, digestion was stopped by the addition of iodoacetic acid (final concentration, $0.025 \mathrm{M}$ ). To each reaction mixture, $2.0 \mathrm{~g}$ of insoluble enzyme and $0.6 \mathrm{ml}$ of $60 \%$ sucrose were added.

After incubation for $15 \mathrm{hr}$, the O.D. at $420 \mathrm{~m} \mu$ of diluted supernatant solution of the mixture was measured, $\mathrm{C}$ : no factor was added, $\mathrm{T}$ : the factor treated by the papain for the time indicated above was added.

diluted supernatant solution of reaction mixture was obtained as shown in Fig. 2.

The fractions indicated by the bar in Fig. 1 were pooled and used as glycogen valuelowering factor which had no activity to liberate reducing sugars from sucrose as measured by the method of Somogyi. ${ }^{51}$

5) M. Somogyi, J. Biol. Chem., 160, 399 (1938); idem, ibid., 195, 19 (1952).
The effects of the factor on the synthesis of polymer by the insoluble enzyme are shown in Fig. 2 which indicates that the factor lowers the glycogen values of the polymer.

On the other hand, the addition of the factor did not decrease the contents of fructose in the polymer produced by insoluble enzyme (Table II). These results indicate that the factor does not inhibit the synthesis of fructan but lowers the glycogen value of it.

The factor may be a protein in nature, for its activity was disappeared by papain digestion as shown in Fig. 3. By heat treatment $\left(100^{\circ} \mathrm{C}\right.$ for $\left.5 \mathrm{~min}\right)$ the activity was also lost.

From the results described above, it is obvious that the water-insoluble preparations of crude dextransucrase synthesize the fructan with higher glycogen values in the absence of the factor, but synthesize the fructan with lower glycogen values in the presence of the factor.

If the glycogen values reflect the branching structure of the fructan, it is very interesting to examine the possibility that the factor controls the branching of the fructan produced by insoluble enzyme.

Acknowledgement. The author gratefully thanks Prof. K. Arima of Tokyo Univ. for his helpful suggestion and for supplying the strains of $L$. mesenteroides.

He also thanks Drs. T. Beppu and T. Uozumi of Tokyo Univ. for helpful discussions and suggestions. He acknowledges the encouragement by Mr. H. Matsui, 
Senior Researcher of Research Department, Pharmaceuticals Division of his company throughout this work.
Research Department, Pharmaceuticals Division of Sumitomo Chemical Co., Ltd. Takarazuka, Hyogo Prefecture 